\title{
DOES TAKING A PHD ABROAD INCREASE THE NUMBER OF INTERNATIONAL PUBLICATIONS? REFLECTIONS FROM THE BEST SELF-REPORTED PUBLICATIONS IN PORTUGUESE ACADEMIA
}

\author{
S. Diogo ${ }^{1,2,3}$, R. Biscaia ${ }^{1} \&$ T, Carvalho ${ }^{1,2}$ \\ ${ }^{1}$ Universidade de Aveiro (PORTUGAL) \\ ${ }^{2}$ CIPES Research Unit (PORTUGAL) \\ ${ }^{3}$ GOVCOPP Research Unit (PORTUGAL)
}

\begin{abstract}
This paper contributes to the debate on academics' internationalisation and academic research productivity by focusing on knowledge diffusion. Public policies on science and technology developed in Portugal in the last years have fostered an increase in the number of PhD graduates, and incite them to study abroad. Consequently, many PhD students have been studying outside Portugal. Simultaneously, international publications have been assuming an increasing relevance in researcher's recruitment and career advancement. Taking those PhD graduates who have a contractual relation with a higher education institution ( $\mathrm{HEl}$ ), this study analyses if having a $\mathrm{PhD}$ abroad matters to the way researchers disseminate the knowledge they produce. Conclusions show a positive effect between taking the $\mathrm{PhD}$ abroad and reporting a higher number of international articles. However, and contrary to our expectations, when separating this result between ISCED-97 Fields of Education, such outcomes only hold for the areas of "Arts and Humanities" and "Social Sciences, Commerce and Law", being ineffective or even having the contrary effect for all other areas.
\end{abstract}

Keywords: Self-reported Research Productivity; Internationalization of staff; Portuguese higher education institutions; Self-reported publications

\section{INTRODUCTION}

The advent of the knowledge society created increased concerns to the nation-states to align their scientific and innovation policies, while promoting competitiveness and economic growth in the world. The policy measures applied to foster national innovation systems and HEls - key players in the production and dissemination of knowledge - are consolidated in the establishment of the European Research Area (ERA) and in the European Higher Education Area (EHEA) [1]. These two settings also represent the changing dynamics of international academic mobility, which, in turn, can be translated in an increase of extramural collaboration and its importance in academic research activities over the last few decades [2-7].

One of the facets of knowledge production is research performance and research outputs, which, in HEls is usually measured in terms of the number of publications produced (e.g. peer-reviewed journals, conference proceedings, book chapters) by individuals and/or research groups $[8,9]$. With New Public Management and managerialism and its emphasis in performance indicators, higher education (HE) systems in developed economies have been adopting 'research performance frameworks', which have culminated in the transformation of research assessment systems by emphasising academics' knowledge production and dissemination, especially through international publications [11; 12]. One of the flagships of the Bologna process and consequently of the creation of the EHEA was the aim of increasing staff mobility and cooperation in order to promote European $\mathrm{HE}$ internationalisation and modernization [16, 17]. However, it is challenging to find consensus in the literature on how these processes - staff mobility, internationalisation and modernization of HE have a positive impact on international research collaboration and/or whether they enhance publication performance (Decramer, Goeminne [8]. In turn, the literature [7, 18-25] evidences that scientific productivity and research performance increase when researchers have international experiences, which include being part of transnational professional networks in their home country, spent some time 
abroad [26-30] or having scientific international cooperation [6, 7, 26, 31-33]. Integration in international research networks is thus seen as crucial to stay at the cutting edge of a science, and to guarantee a stable and significant output [34-36].

Trying to analyse if there is a relationship or an impact between academic international experiences and individuals (academics) research productivity, we ask whether having graduated abroad favoured a different profile for disseminating knowledge produced with a higher emphasis on publishing internationally. We believe this is the case, given the higher de facto orientation that foreign countries may have towards publications in international outlets when compared to Portugal $[6,37]$ and the fact that being abroad improves researchers knowledge of a second (or even a third) language.

The paper aims thus to shed a light on the publication patterns that arise in a given national research system. Bearing in mind that the internationalisation of the academy varies according to individual, institutional and structural characteristics, and that among factors influencing it, discipline plays a major role [12, 39-41], we will be able to assess whether the different types of outputs reported by researchers are dependent on their characteristics, with the main factor eventually being the international experiences of the staff. The next section introduces some food for thought on internationalisation of academia. It then follows with a contextualisation of the Portuguese HE and scientific system and an explanation about the methods employed to collect and analyse data for this paper. The next section is devoted to analyse the data followed by the conclusions and proposals for further research.

\section{THEORETICAL BACKGROUND}

The internationalisation of the academic profession is usually measured through three aspects: international research collaboration, international mobility and international teaching [39, 42]. For the purpose of this study, we will focus only in international mobility and more specifically within the framework of a PhD student. According to Rostan and Ceravolo [35], international research includes collaboration in research efforts with international colleagues, and obtaining funding for research from international organisations. In fact, the literature is consistent with the idea that research productivity has become a significant indicator of (European) universities' quality [7, 8, 38], a fact that explains the increase of extramural collaboration in academic research activities $[2,6,36]$. An analysis to the Science Citation Index reveals a significant increase in the number of publications elaborated through international collaboration (internationally co-authored papers) from 1990 to 2000 [3, 41-45]. In this way, counting the number of publications has become a common practice for assessing performance within academia and universities are increasingly looking to research outputs [8, 46, 47]. International research is thus connected to international dissemination, "i.e. publishing in a language different from the language of instruction currently employed at the home institution, publishing in a foreign country, and co-authoring a publication with colleagues located in other countries [2]. In turn, as the literature refers $[2,52]$ this incidence of extramural collaboration happens due to an increase of policy measures aiming at fostering partnership and networking among the various components of the research system, based on the strong belief that knowledge sharing could increase the effectiveness of the national $\mathrm{HE}$ and research systems. Among these policies, stands the increase of international mobility within academia. Mobility usually refers to diverse actions such as earning an advanced degree abroad (e.g. a PhD), travelling for professional purposes, and moving to another country to get a job. Here, we refer mostly to voluntary mobility, and not to situations where mobility is effectively 'forced' due to lack of work or inability to access positions [26]. Simultaneously, it is important to refer that NPM and managerialism have been dictating institutional governance models which, increasingly more, emphasise 'control technologies' in the form of practical measures as target setting or performance management [13, 49-52]. Some of these international academic activities entail the crossing of state borders while others occur 'at home' [2]. On this, Kwiek [23] refers that one of the sides of internationalization is stratification as more international collaboration tends to mean higher publishing rates. In this way, those who do not collaborate internationally may be lagging behind in terms of resources and prestige in the academia. International collaborations and networks are then important processes in improving the quality of research $[8,37,40]$. Research productivity and competition are thus hand in hand and they are becoming permanent features of the European research landscape. It seems also natural that spending time in different universities, either lecturing and/or researching, allows academics to build networks which, in turn, will lead to (more) contacts and feedback from peers, and consequently, and very likely, to an increase in the number of publications. Edler, Fier [21], Decramer, Goeminne [8] also state that the more frequently scientists are internationally mobile during their career, the more they engage in knowledge and technology transfer 
activities. Bearing in mind the (positive) relationship between internationalisation, mobility and scholarly research performance, the literature also highlights the relationship between academics' behaviour in terms of performance indicators and their disciplines. Rostan and Ceravolo [35] studied convergent and divergent patterns between (the effect of) disciplines and academics' involvement in international research collaborations, taking into account similar factors as we did for this study, namely: individual biographical features (e.g. gender, age), organisational and professional factors linked to the discipline, and the type and location of the institution where the $\mathrm{PhD}$ degree was obtained. Based on two international comparative studies (the Changing Academic Profession Study and the Academic Profession in Europe Study), Rostan and Ceravolo [35] concluded that the fact of belonging to a discipline makes a difference in academics' involvement in international research networks (divergent patterns), considering that this is more frequent among academics from science, less frequent among academics from humanities, social sciences and engineering, with those from the medical sciences in between. Nevertheless, the authors drawn our attention to the fact that international research collaboration do not depends only on discipline, being this process shaped by other factors such as career stage and structural features of the contexts within which research activities are performed (e.g. country characteristics, cf. [13]. Rostan and Ceravolo [35] also refer that working in small countries (as well as in wealthier countries) increases the likelihood of collaborating internationally. In this study, we only have data targeting academics working in Portuguese HEls; however, as one will see later on, and comparing with the data provided by the Directorate-General of Statistics for Education and Science [58] in general terms, this study complies with the literature, being possible to strongly believe that collaborating with international colleagues has a positive impact on academics' productivity as measured through the self-reported number of articles published in a context of institutional evaluation.

\section{THE PORTUGUESE HIGHER EDUCATION SYSTEM}

In spite of being one of the oldest HE systems in Europe, Portuguese policies for science and innovation only started at the end of the 1960s. It was mostly based on public laboratories and governmental institutes, with HEls having a minor role in the research system. After the adhesion of Portugal to the European Economic Community in 1986, these national policies were pushed with the development of the European policies. Later, the emergence of the structural funds; the creation of the Ministry of Science and Technology in 1995 and the appearance of the National Scientific Foundation (FCT) in 1997 led to an undeniable development of Science and Technology in the country [44, 45]: the Foundation had the powers to coordinate public policy in terms of science; to fund and evaluate research institutions and to articulate the Portuguese research network, and was so relevant that the history of Portuguese Scientific and Innovation Policies is blurred with the history of FCT itself [11]. From then on, HEl gained relevance in the scientific system. A legal status was given to their research units in 1998, which were the main characters in the quest for scientific production, along with the already existing public laboratories $[11,51]$. With the dawn of the new millennium, new trends for a stronger connection of research efforts with the real economy led to a significant increase of the public investments in R\&D and a higher involvement of firms in that R\&D expenditure. In 1995, R\&D expenditure was $0.5 \%$ of GDP, rising to $1.6 \%$ in 2009 , with firms being responsible for 0.7 of those percentile points. However, these values are still below the EU average in $2014(2.04 \%$ in the EU; $1.3 \%$ in Portugal), which serves as a reminder that even if there has been a significant national development regarding these issues, Portugal still occupies a peripheral position in the ERA [62]. The development of the Scientific and Innovation Policies coupled with the massification of HE that occurred in Portugal during the eighties and nineties has led to a significant increase in the number of Doctorates in Portugal, given that in order to progress in the HE career the PhD degree was necessary. Such mandatory need for a PhD started in 1979, in a period where most Portuguese Institutions did not have their own PhD programs, and so the proportion of academics in Portugal that resorted to foreign HEls in order to obtain their degree was relatively high. Progressively, and since the moment Universities started to provide their own PhD Programs, the proportion of PhD foreign graduates decreased significantly. Data show the significant increase in the total number of PhD Graduates over time, with nearly 5200 graduates in the nineties comparing to nearly 12000 in the nineties and with nearly 8500 graduates in only four years of this decade. This tendency of growth is also verified in the number of $\mathrm{PhDs}$ taken in foreign countries, even though the $\mathrm{PhD}$ attribution in Portugal is more than consolidated, revealing that there is still some interest from $\mathrm{PhD}$ students to obtain their degrees on a different country. This increase in the number of Graduates cannot be disassociated from the significant increase in the number of PhD Scholarships attributed by the National Science Foundation in the decades of 1990s and 2000s [14]. In line with the increase in the 
number of PhD graduates and the consolidation of those $3^{\text {rd }}$ cycle courses, but as well as with the increasing trend and pressures on the production and dissemination of knowledge in international outlets (see, for instance, [11], the number of publications associated with Portuguese HEls has been increasing significantly. For instance, comparing the years of 2005 and 2015 with the number of Articles, Letters, Notes and Reviews per million inhabitants in the Web of Science database, this figure for 2015 is more than double when comparing to 2005, with a growth rate that surpasses that of the European Union [65]. Even though the proportion of foreign PhD graduates has been decreasing in the last year, it is relevant to ask whether those foreign PhD students that returned to Portuguese $\mathrm{HEls}$ are, in fact, more capable/oriented to publish their work in international journals or books when compared to the Portuguese staff that completed the PhD in Portugal. As discussed in section 2, the paper is based on the assumption, in accordance with the literature review that the effect of such foreign experience could be positive, and therefore it will be tested empirically through the next sections.

\section{METHODOLOGY}

Using a dataset of 9602 staff members of Portuguese HEls coming from a mandatory questionnaire by the Portuguese Agency for Assessment and Accreditation of Higher Education (A3ES) (2010/2011)1, we attempt to explore the relationship between the self-reported publication patterns of these staff and the HEl where they obtained their PhD degree, namely if it was abroad or in a Portuguese institution. To tackle this issue, statistical inference and econometrics methods were used in order to assess whether this relationship is significant. We have also broken down the analysis into different scientific fields - provided that there are enough observations in each field - to check whether this relationship holds for each scientific field. Regarding the publication patterns, the respondents were asked to input their five publications that they considered the most relevant. Taking the fact that HEls were evaluated according to the publication metrics, the international publications, and especially those in international indexed journals, were highly valued. Taking this, we assume that the respondents tended to refer to all the publications (or at least the most relevant) they had in this category. We disentangle these publications between their types, namely, whether the publication was an authored or co-authored scholarly book and/or book chapter, edited or co-edited scholarly books, a peer-reviewed journal article, a conference proceeding and an artistic output. This confirms Decramer, Goeminne [8] idea that a research output is a multidimensional variable. Among all these types of publications, we have separated them between national and international. Therefore, our main variables of analysis are related with the number of different types of outputs that the staff selfreported in the questionnaire. The dataset has also information about the staff's career and sociodemographic characteristics, which we use as control variables in relation to our main research question. On the side of the explanatory variables, our main variable of interest is a dummy variable identifying whether the respondent has taken a PhD abroad or not. We use other information in order to build the control variables, namely, i) the Year that the respondents completed their PhD; ii) the ISCED-97 field of education of their PhD; iii) the type of institution that the respondents were mainly affiliated with; and iv) the gender of the respondent. Table 2 presents the statistical inference for all these variables.

Table 2 - Statistical Inference for the variables used in the linear regression

\begin{tabular}{llccc}
\hline $\begin{array}{l}\text { Dependent } \\
\text { Variables }\end{array}$ & Variable Description & N & Minimum & $\begin{array}{c}\text { Maximum } \\
\text { Mean } \\
\text { Deviation }\end{array}$ \\
\hline $\begin{array}{l}\text { Articles in } \\
\text { International } \\
\text { Journals }\end{array}$ & $\begin{array}{l}\text { Number of articles in } \\
\text { international journals }\end{array}$ & $\mathrm{N}=9602$ & 0 & 1.879 \\
\hline $\begin{array}{l}\text { Number of } \\
\text { International } \\
\text { Outputs }\end{array}$ & $\begin{array}{l}\text { Number of publications in any } \\
\text { type of international publication } \\
\text { outlets }\end{array}$ & $\mathrm{N}=9602$ & 0 & 5 \\
\hline $\begin{array}{l}\text { Total Number of } \\
\text { Number of publications in any }\end{array}$ & $\mathrm{N}=9602$ & 0 & 2.20 \\
\hline
\end{tabular}
1 This covers nearly all doctorates in Portugal, given that, in 2012, 83\% of the PhD were employed in the higher education
sector [57]. 


\begin{tabular}{|c|c|c|c|c|c|c|}
\hline Outputs & type of publication outlets & & & & & \\
\hline $\begin{array}{l}\text { Explanatory } \\
\text { Variables }\end{array}$ & Variable Description & $\mathbf{N}$ & Minimum & Maximum & Mean & $\begin{array}{l}\text { Standard } \\
\text { Deviation }\end{array}$ \\
\hline $\begin{array}{l}\text { PhD } \\
\text { Abroad }\end{array}$ & $\begin{array}{l}\text { Dummy Variable, assuming } \\
\text { value } 1 \text { when the respondent } \\
\text { took the PhD Abroad }\end{array}$ & $N=9589$ & 0 & 1 & 0.2700 & 0.4440 \\
\hline Male & $\begin{array}{l}\text { Dummy Variable, assuming } \\
\text { value } 1 \text { when the respondent is } \\
\text { a male. }\end{array}$ & $N=9602$ & 0 & 1 & 0.5981 & 0.4903 \\
\hline Year PhD & $\begin{array}{l}\text { Year in which the PhD was } \\
\text { completed by the respondents }\end{array}$ & $\mathrm{N}=9545$ & 1940 & 2012 & 1999.85 & 7.813 \\
\hline $\begin{array}{l}\text { Private } \\
\text { University }\end{array}$ & $\begin{array}{l}\text { Dummy Variables assuming } \\
\text { value } 1 \text { when the respondents } \\
\text { were affiliated with an HEI of } \\
\text { that type. "Public University" is }\end{array}$ & $N=9532$ & 0 & 1 & 0.1668 & 0.3728 \\
\hline $\begin{array}{l}\text { Public } \\
\text { Polytechnic }\end{array}$ & for this group of variables. & $N=9532$ & 0 & 1 & 0.1280 & 0.3341 \\
\hline $\begin{array}{l}\text { Private } \\
\text { Polytechnic }\end{array}$ & & $N=9532$ & 0 & 1 & 0.0158 & 0.1249 \\
\hline $\begin{array}{l}\text { General } \\
\text { Programmes }\end{array}$ & $\begin{array}{l}\text { Dummy Variables assuming } \\
\text { value } 1 \text { when the respondents }\end{array}$ & $\mathrm{N}=9545$ & 0 & 1 & 0.0004 & 0.0205 \\
\hline $\begin{array}{l}\text { Arts and } \\
\text { Humanities }\end{array}$ & $\begin{array}{l}\text { of Education. The Field of } \\
\text { "Education" is omitted, being the } \\
\text { base category for this group of }\end{array}$ & $\mathrm{N}=9545$ & 0 & 1 & 0.1252 & 0.3310 \\
\hline $\begin{array}{l}\text { Social Sciences, } \\
\text { Business and } \\
\text { Law }\end{array}$ & & $\mathrm{N}=9545$ & 0 & 1 & 0.2214 & 0.4152 \\
\hline Science & & $N=9545$ & 0 & 1 & 0.2586 & 0.4379 \\
\hline $\begin{array}{l}\text { Engineering, } \\
\text { Manufacturing } \\
\text { and Construction }\end{array}$ & & $N=9545$ & 0 & 1 & 0.1990 & 0.3992 \\
\hline Agriculture & & $N=9545$ & 0 & 1 & 0.0244 & 0.1543 \\
\hline $\begin{array}{l}\text { Health and } \\
\text { Welfare }\end{array}$ & & $\mathrm{N}=9545$ & 0 & 1 & 0.1007 & 0.3009 \\
\hline Services & & $N=9545$ & 0 & 1 & 0.0228 & 0.1494 \\
\hline $\begin{array}{l}\text { Area not } \\
\text { Reported }\end{array}$ & & $N=9545$ & 0 & 1 & 0.0027 & 0.0052 \\
\hline
\end{tabular}

With respect to the dependent variables, it is clear that there is a significant difference between considering only international journal articles and all the outputs. In fact, nearly $50 \%$ (1.64 of the 3.30 mean) of publications referred were international journal articles. This also hints that, as expected, the respondents preferred to indicate, whenever possible, their international journal articles instead of other types of publications that were asked in the questionnaire. ${ }^{2}$ This behaviour goes in line with the tendencies discussed in the literature $[9,13,37,38,44,47,58]$ for researchers to comply with the new values and principles, which nowadays frame the research systems. We can also recall our boundary

${ }^{2}$ Of course, this will hold differently between different fields of education, as we know that in Social Sciences and/or Humanities, other types of publications may be considered as well in the "first tier", such as international and national books [13]. 
of a maximum of 5 publications that each respondent could submit. In terms of our main explanatory variable, we can see that $27 \%$ of the respondents completed their $\mathrm{PhD}$ on a foreign $\mathrm{HEI}$, which is a relatively significant number, reflecting our contextualization of the Portuguese HE staff in the previous section. From the other dummy variables, the sample comprises $60 \%$ of males; the great majority of staff being in a Public University, with the other three types only representing $31.06 \%(0.1668+$ $0.1280+0.0158$ ) of the sample; The scientific area with the highest proportion of PhD staff is Science $(25.86 \%)$ followed by Social Sciences, Business and Law (22.14\%) and Engineering, Manufacturing and Construction (19.90\%). Regarding the PhD completion, the average year of the completion of the $\mathrm{PhD}$ is near the year 2000, meaning that, on average, the PhD staff working in HEls had twelve years of career as doctorates.

\section{ESTIMATION OF RESULTS}

\subsection{For the Entire Sample}

With the variables that were explained before, we proceed on the estimation of the Linear Regression Models. In Table 3, we have the estimations for the three different dependent variables we want to test. Model 1 assumes as dependent variable the "Number of Articles in International Journals" that were reported by the respondents. Model 2 assumes a broader definition for publications and includes all international outlets in the variable "Number of International Outputs". Model 3 considers all the publications that were reported by the respondents in the variable "Total Number of Outputs".

Table 3 - Linear Regression Models for the whole sample.

\begin{tabular}{|c|c|c|c|}
\hline \multirow[t]{3}{*}{ Explanatory Variables } & $\begin{array}{c}\text { Model } 1 \text { - Number of } \\
\text { Articles in } \\
\text { International } \\
\text { Journals }\end{array}$ & $\begin{array}{l}\text { Model } 2 \text { - Number of } \\
\text { International Outputs }\end{array}$ & $\begin{array}{c}\text { Model } 3 \text { - } \\
\text { Total Number of } \\
\text { Outputs }\end{array}$ \\
\hline & Coefficients. (SE) & Coefficients. (SE) & \\
\hline & & & Coefficients. (SE) \\
\hline Constant & $30.677^{\star \star \star}(4.875)$ & $20.294^{* \star *}(5.251)$ & $30.161^{* * *}(5.614)$ \\
\hline PhD Taken Abroad & $0.168^{* * *}(0.042)$ & $0.279^{* * *}(0.045)$ & $-0.083^{*}(0.049)$ \\
\hline Male & $-0.158^{* * *}(0.036)$ & $-0.144^{* * *}(0.039)$ & $-0.061(0.042)$ \\
\hline Year in which PhD was Granted & $-0.115^{\star * *}(0.002)$ & $-0.009^{* * *}(0.003)$ & $-0.013^{*}(0.003)$ \\
\hline \multicolumn{4}{|c|}{ Type of Institution (Base Category - Public Universities) } \\
\hline Private University & $-0.712^{\star * *}(0.049)$ & $-0.626^{* * *}(0.053)$ & $-0.277^{* * *}(0.057)$ \\
\hline Public Polytechnic & $-0.442^{* * *}(0.055)$ & $-0.351^{* * *}(0.059)$ & $-0.306^{* * *}(0.063)$ \\
\hline Private Polytechnic & $-0.541^{* * *}(0.141)$ & $-0.552^{\star * *}(0.152)$ & $0.162(0.162)$ \\
\hline \multicolumn{4}{|c|}{ ISCED-97 Field of Education (Base Category - Education) } \\
\hline General Programmes & $-0.194(0.849)$ & $-0.470(0.914)$ & $0.828(0.977)$ \\
\hline Arts and Humanities & $-0.165^{\star}(0.098)$ & $-0.182^{*}(0.106)$ & $0.162(0.113)$ \\
\hline $\begin{array}{r}\text { Social Sciences, Business and } \\
\text { Law }\end{array}$ & $0.539^{* * *}(0.093)$ & $0.526^{\star \star *}(0.100)$ & $0.217^{* *}(0.107)$ \\
\hline Science & $1.833^{\star \star \star}(0.092)$ & $1.832^{* * *}(0.099)$ & $0.450^{* * *}(0.106)$ \\
\hline $\begin{array}{r}\text { Engineering, Manufacturing and } \\
\text { Construction }\end{array}$ & $1.014^{* * *}(0.094)$ & $1.286^{\star \star *}(0.102)$ & $-0.026(0.109)$ \\
\hline
\end{tabular}




\begin{tabular}{rccc}
\hline Agriculture & $1.910^{* * *}(0.140)$ & $1.882^{* * *}(0.150)$ & $0.843^{* * *}(0.161)$ \\
\hline Health and Welfare & $1.548^{* * *}(0.101)$ & $1.452^{* * *}(0.109)$ & $0.162(0.117)$ \\
\hline Services & $1.558^{* * *}(0.144)$ & $1.664^{* * *}(0.155)$ & $0.850^{* * *}(0.166)$ \\
\hline Area not Reported & $0.649^{* *}(0.342)$ & $0.575(0.369)$ & $-0.473(0.394)$ \\
\hline Number of observations & 9422 & 9422 & 9422 \\
\hline F-statistic & $152.493^{* * *}$ & $125.137^{* * *}$ & $15.152^{* * *}$ \\
\hline $\boldsymbol{R}^{2}$ & 0.196 & 0.166 & 0.024 \\
\hline
\end{tabular}

* - Significant at 10\%; ** - Significant at 5\%; ${ }^{* * *}$ - Significant at $1 \%$

The results confirm some of our initial expectations. Firstly, and in terms of our main variable of interest, for model 1 and for model 2, we find that the fact that the respondent has taken a PhD abroad contributes positively to the a) Number of Articles in International Journals and b) Number of international Outputs at the highest statistical significance. Remember that this is a linear regression containing multiple variables, and therefore, the result obtained for this "PhD abroad" variable is obtained, assuming all other variables are constant, or controlled for. This means that, on average, respondents that have taken their PhD abroad, which come from an institution of the same type; from the same scientific area; that concluded their $\mathrm{PhD}$ at the same year and that have the same gender; will, on average, self-report more 0.168 articles in international journals and 0.279 articles in international outlets than respondents that have taken their $\mathrm{PhD}$ in Portugal. This supports our belief that these dissemination mechanisms and the research orientation/strategy of the respondents are changed significantly after taking the $\mathrm{PhD}$ abroad. ${ }^{3}$

Secondly, we comment on the results of the other control variables that we have considered in our model. For gender differences, we find that for models 1 and 2 , males tend to publish about 0.15 international articles less than females, given that all their other characteristics remain the same, in a result that might be attributed to the better performance that females usually obtain throughout their education [73]. These findings somehow show a different view from Rostan and Ceravolo [39] study, as well as other literature on gender differences by scientific productivity [74], who referred that academic males are more likely to collaborate with international colleagues than females. Also Børing, Flanagan [62] refer that female respondents are less likely to have experienced international mobility at some point in their research career than male respondents. Nevertheless, we say "somehow" because the relationship between international collaboration and the (high) number of publications is, as we have seen, not linear or simplistic. Also [76] refer that this difference in research outputs analysed by gender tends to happen more due to institutional factors rather than individual preferences or options. Our model also reveals that for each year that the respondent finished his/her $\mathrm{PhD}$ later, this means 0,115 less international journal articles. This result is very logical, given that most likely the respondents that finished their $\mathrm{PhD}$ more recently had less time to develop their research careers, and therefore, to have their work published in international journals. Furthermore, several analyses conclude that the academic position is a relevant variable in explaining publication variation with those in higher positions publishing more [13, 73-75].

In terms of types of institutions, we arrive at the result, and focusing only on model 1, even though model 2 yielded similar results, that the respondents from Public Universities reported more 0.712; 0.442 and 0.541 articles in international journals when comparing with Private Universities, Public Polytechnics and Private Polytechnics, respectively. This result clearly illustrates the differences between the 4 subsectors in Portugal, with the Public University being normally associated with higher research productivity and/or international dissemination of results- which is reinforced with our results - irrespectively of other characteristics of staff, being in the Public University means more international publications. With respect to the ISCED 97 Fields of Education in which the respondents declared

\footnotetext{
${ }^{3}$ While the value for the estimates $(0,168$ and 0,279$)$ do not seem that high, one should remember that the respondents were
} bounded and could only declare 5 of their publications. 
their PhD to be on, and given that we considered the field of "Education" as the base category for all our analysis, the results show that all other fields except for "General Programmes" and "Arts and Humanities" (in which the differences are not significant), have a higher number of "Articles in International Journals" than the field of "Education". The results are expected, in the sense that we know that some fields are more prone to obtain specific research outputs and to do their dissemination internationally $[62,81]$. The fields in which the respondents had, on average, more than one Article in International Journals than in the field of "Education" were, less surprisingly, "Science", "Health and Welfare", "Engineering, Manufacturing and Construction" and, more surprisingly, "Services" and "Agriculture".

Thirdly, we have to refer to overall significance of these linear regressions. Model 1 and Model 2 present an R-Squared value of 0.196 and 0.166 respectively, meaning that the variations of the dependent variable are $19.6 \%$ and $16.6 \%$ explained by the variation of the explanatory variables. These numbers are quite satisfactory in Linear Regression Models, given that these are enough to prove the significance that these explanatory variables have to explain our dependent variables. We have not referred to Model 3 in this results section so far exactly because of this reason. The model, which includes "Total Number of Outputs" as the dependent variable, has an R-Squared value of only $2.4 \%$, and therefore, much less explanatory value. The reason is that Model 3 has as dependent variable all publications, and therefore those that could not declare international publications declared the national ones. Given that the cap in the questionnaire were 5 publications, most people, irrespectively of their area and PhD characteristics, could more easily find 5 publications of any type instead of more specific publications, such as International ones (Model 2) or even just Articles in International Journals (Model 1).

\subsection{By Fields of Education}

Given that we have found the result that taking a $\mathrm{PhD}$ abroad might be relevant on attaining a higher number of International Publications, we wanted to see if this result still held with a breakdown of the sample between the different fields of education. That is, we want to see whether this is true for all fields of education, or only for a few, and under which conditions. Therefore, we divide the sample for both models 1 and 2, and removed accordingly the fields of education variables from the set of explanatory variables. The results are detailed (Tables 4 and 5) for model 1 and model 2, respectively.

Table 4 - Regressions for Articles in International Journals by Fields of Education

\begin{tabular}{|c|c|c|c|c|c|c|c|c|}
\hline $\begin{array}{l}\text { Explanatory } \\
\text { Variables } \\
\text { (Dependent } \\
\text { Variable: } \\
\text { Articles in } \\
\text { Inter. } \\
\text { Journals }\end{array}$ & $\begin{array}{c}\text { Model } 1.1 \\
\text { Educatio } \\
\mathbf{n}\end{array}$ & $\begin{array}{c}\text { Model } 1.2 \\
\text { Arts and } \\
\text { Humaniti } \\
\text { es }\end{array}$ & $\begin{array}{c}\text { Model } 1.3 \\
\text { Social } \\
\text { Sciences, } \\
\text { Commerc } \\
\text { e and } \\
\text { Law }\end{array}$ & $\begin{array}{l}\text { Model } 1.4 \\
\text { Sciences }\end{array}$ & $\begin{array}{c}\text { Model } 1.5 \\
\text { Engineeri } \\
\text { ng, } \\
\text { Manufact } \\
\text { uring and } \\
\text { Construc } \\
\text { tion }\end{array}$ & $\begin{array}{c}\text { Model } 1.6 \\
\text { Agricultu } \\
\text { re }\end{array}$ & $\begin{array}{c}\text { Model } 1.7 \\
\text { Health } \\
\text { and } \\
\text { Welfare }\end{array}$ & $\begin{array}{c}\text { Model } 1.8 \\
\text { Services }\end{array}$ \\
\hline Constant & $\begin{array}{l}48.316^{\star * *} \\
(18.508)\end{array}$ & $\begin{array}{l}5.290 \\
(6.991)\end{array}$ & $\begin{array}{l}10.670 \\
(9.624)\end{array}$ & $\begin{array}{l}65.193^{* \star *} \\
(11.030)\end{array}$ & $\begin{array}{l}41.183^{\star * *} \\
(11.516)\end{array}$ & $\begin{array}{l}32.245 \\
(40.118)\end{array}$ & $\begin{array}{l}28.200^{*} \\
(15.645)\end{array}$ & $\begin{array}{l}11.681 \\
(41.513)\end{array}$ \\
\hline $\begin{array}{r}\text { PhD Taken } \\
\text { Abroad }\end{array}$ & $\begin{array}{l}0.103 \\
(0.130)\end{array}$ & $\begin{array}{l}0.219^{* * *} \\
(0.060)\end{array}$ & $\begin{array}{l}0.703^{* * *} \\
(0.073)\end{array}$ & $\begin{array}{l}-0.157 \\
(0.097)\end{array}$ & $\begin{array}{l}-0.283^{* *} \\
(0.109)\end{array}$ & $\begin{array}{l}-0.009 \\
(0.320)\end{array}$ & $\begin{array}{l}0.123 \\
(0.169)\end{array}$ & $\begin{array}{l}-0.192 \\
(0.382)\end{array}$ \\
\hline Male & $\begin{array}{l}0.038 \\
(0.108)\end{array}$ & $\begin{array}{l}-0.184^{* * *} \\
(0.051)\end{array}$ & $\begin{array}{l}-0.013 \\
(0.069)\end{array}$ & $\begin{array}{l}-0.108 \\
(0.079)\end{array}$ & $\begin{array}{l}-0.345^{\star * *} \\
(0.094)\end{array}$ & $\begin{array}{l}-0.527^{* *} \\
(0.255)\end{array}$ & $\begin{array}{l}-0.351^{* *} \\
(0.137)\end{array}$ & $\begin{array}{l}0.218 \\
(0.270)\end{array}$ \\
\hline PhD Year & $\begin{array}{l}-0.024^{* * *} \\
(0.009)\end{array}$ & $\begin{array}{l}-0.002 \\
(0.003)\end{array}$ & $\begin{array}{l}-0.005 \\
(0.005)\end{array}$ & $\begin{array}{l}-0.031^{* * *} \\
(0.006)\end{array}$ & $\begin{array}{l}-0.020^{\star * *} \\
(0.006)\end{array}$ & $\begin{array}{l}-0.014 \\
(0.020)\end{array}$ & $\begin{array}{l}-0.013 \\
(0.008)\end{array}$ & $\begin{array}{l}-0.005 \\
(0.021)\end{array}$ \\
\hline \multicolumn{9}{|c|}{ Type of Institution } \\
\hline $\begin{array}{r}\text { Private } \\
\text { University }\end{array}$ & $\begin{array}{l}-0.338^{* *} \\
(0.141)\end{array}$ & $\begin{array}{l}-0.302^{\star \star \star} \\
(0.062)\end{array}$ & $\begin{array}{l}-0.786^{\star \star \star} \\
(0.079)\end{array}$ & $\begin{array}{l}-1.096^{\star * *} \\
(0.154)\end{array}$ & $\begin{array}{l}-0.749^{\star * \star} \\
(0.131)\end{array}$ & $\begin{array}{l}-1.459^{\star * \star} \\
(0.488)\end{array}$ & $\begin{array}{l}-0.861^{\star \star \star} \\
(0.167)\end{array}$ & $\begin{array}{l}-1.077^{\star \star *} \\
(0.384)\end{array}$ \\
\hline $\begin{array}{r}\text { Public } \\
\text { Polytechnic }\end{array}$ & $\begin{array}{l}-0.162 \\
(0.153)\end{array}$ & $\begin{array}{l}-0.286^{* * *} \\
(0.085)\end{array}$ & $\begin{array}{l}-0.720^{* \star *} \\
(0.109)\end{array}$ & $\begin{array}{l}-0.610^{\star * *} \\
(0.132)\end{array}$ & $\begin{array}{l}-0.151 \\
(0.104)\end{array}$ & 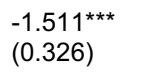 & $\begin{array}{l}-0.603^{* *} \\
(0.276)\end{array}$ & $\begin{array}{l}-0.244 \\
(0.494)\end{array}$ \\
\hline $\begin{array}{r}\text { Private } \\
\text { Polytechnic }\end{array}$ & $\begin{array}{l}-0.152 \\
(0.224)\end{array}$ & $\begin{array}{l}-0.238 \\
(0.175)\end{array}$ & $\begin{array}{l}-1.083^{* * *} \\
(0.234)\end{array}$ & $\begin{array}{l}-0.584 \\
(0.444)\end{array}$ & $\begin{array}{l}-0.563 \\
(0.508)\end{array}$ & $\begin{array}{l}-2.170 \\
(1.903)\end{array}$ & $\begin{array}{l}0.223 \\
(0.493)\end{array}$ & $\begin{array}{l}-1.172 \\
(0.793)\end{array}$ \\
\hline
\end{tabular}




\begin{tabular}{rllllllll}
\hline $\begin{array}{c}\text { Number of } \\
\text { observations }\end{array}$ & 398 & 1182 & 2083 & 2450 & 1882 & 233 & 953 & 211 \\
\hline F-statistic & $2.693^{* *}$ & $9.071^{* * *}$ & $14.964^{* * *}$ & $19.967^{* * *}$ & $10.504^{* * *}$ & $5.839^{* * *}$ & $6.180^{* * *}$ & $2.178^{* *}$ \\
\hline$R^{2}$ & 0,040 & 0,044 & 0,092 & 0,047 & 0,033 & 0,134 & 0,038 & 0,060 \\
\hline
\end{tabular}

* - Significant at 10\%; ${ }^{* *}$ - Significant at 5\%; ${ }^{* * *}$ - Significant at $1 \%$

Interestingly, we found that results vary significantly depending on the field of education that we are considering, at least concerning our main variable of analysis. The variable "PhD Taken Abroad" is now only significant for the Fields of Education of "Arts and Humanities", "Social Sciences, Commerce and Law" and "Engineering, Manufacturing and Construction". For all other areas, the effect of the variable on explaining the number of articles in international journals is not significant, meaning that the fact that the respondent has taken a PhD abroad has no apparent relation with the dependent variable for these fields of education. On the fields in which there was a significant relation identified, the relationship was not monotonic - for Arts and Social Sciences, the relationship proved to be positive, while for engineering this relationship was negative. Hence, we can conclude that while at the system level having a $\mathrm{PhD}$ abroad may lead researchers to disseminate their results in international journal articles, when breaking down by fields of education this theoretical relationship is not so clear, with only two fields attaining such positive relationship. In fact, at this point is where we find more disparate (uneven) results when comparing with the literature. A possible explanation for this result in these specific fields of Education -might lie in the nature of the publication procedures. Having a successful publication in the fields of Humanities and Social Sciences depends more on the way articles are written and structured when compared with, for example, the fields of Engineering or Health and Welfare which tend to be more 'technical'. Therefore, by having a PhD abroad, Humanities and Social Sciences' researchers might have learned "the rules of the game" or have benefitted more from better writing and English language techniques in these fields, in which these questions seem to be relatively more important. On the other side, having an experience abroad may also contribute to develop more comparative approaches, which increases the audience of the paper and may turn it more 'attractive' for publication. Regarding the other variables that were tested, interesting is the fact that irrespectively of the field of education, the differences between being in a Public vs. Private University are always significant and in the same direction: respondents working in a Public University reported more articles in international journals than their Private University counterparts. A relatively weaker effect was identified relatively to the Public Polytechnics, whose respondents proved to be less productive in terms of these outputs for some fields of education. Gender analysis reveals a higher number of international articles written by women in the fields of Arts; Engineering; Agriculture; and Health.

Table 5 - Regressions for Number of International Outputs by Fields of Education

\begin{tabular}{|c|c|c|c|c|c|c|c|c|}
\hline $\begin{array}{l}\text { Explanatory } \\
\text { Variables } \\
\text { (Dependent } \\
\text { Variable: } \\
\text { Number of } \\
\text { Inter. } \\
\text { Outputs }\end{array}$ & $\begin{array}{c}\text { Model } 2.1 \\
\text { Educatio } \\
n\end{array}$ & $\begin{array}{l}\text { Model } 2.2 \\
\text { Arts and } \\
\text { Humaniti } \\
\text { es }\end{array}$ & $\begin{array}{c}\text { Model } 2.3 \\
\text { Social } \\
\text { Sciences, } \\
\text { Commerc } \\
\text { e and } \\
\text { Law }\end{array}$ & $\begin{array}{l}\text { Model } 2.4 \\
\text { Sciences }\end{array}$ & $\begin{array}{c}\text { Model } 2.5 \\
\text { Engineeri } \\
\text { ng, } \\
\text { Manufact } \\
\text { uring and } \\
\text { Construc } \\
\text { tion }\end{array}$ & $\begin{array}{l}\text { Model } 2.6 \\
\text { Agricultu } \\
\text { re }\end{array}$ & $\begin{array}{c}\text { Model } 2.7 \\
\text { Health } \\
\text { and } \\
\text { Welfare }\end{array}$ & $\begin{array}{c}\text { Model } 2.8 \\
\text { Services }\end{array}$ \\
\hline Constant & $\begin{array}{l}64.527^{* *} \\
(25.413)\end{array}$ & $\begin{array}{l}9.036 \\
(10.637)\end{array}$ & $\begin{array}{l}-1.177 \\
(10.851)\end{array}$ & $\begin{array}{l}41.183^{\star \star \star} \\
(11.516)\end{array}$ & $\begin{array}{l}26.804^{* *} \\
(12.608)\end{array}$ & $\begin{array}{l}19.352 \\
(39.155)\end{array}$ & $\begin{array}{l}28.125^{*} \\
(16.023)\end{array}$ & $\begin{array}{l}-40.522 \\
(40.140)\end{array}$ \\
\hline $\begin{array}{r}\text { PhD Taken } \\
\text { Abroad }\end{array}$ & $\begin{array}{l}0.059 \\
(0.130)\end{array}$ & $\begin{array}{l}0.551^{* * *} \\
(0.092)\end{array}$ & $\begin{array}{l}0.916^{* * *} \\
(0.082)\end{array}$ & $\begin{array}{l}-0.283^{* *} \\
(0.109)\end{array}$ & $\begin{array}{l}-0.269^{\star *} \\
(0.119)\end{array}$ & $\begin{array}{l}0.123 \\
(0.313)\end{array}$ & $\begin{array}{l}0.065 \\
(0.173)\end{array}$ & $\begin{array}{l}-0.252 \\
(0.369)\end{array}$ \\
\hline Male & $\begin{array}{l}-0.038 \\
(0.148)\end{array}$ & $\begin{array}{l}-0.270^{* * *} \\
(0.077)\end{array}$ & $\begin{array}{l}-0.098 \\
(0.077)\end{array}$ & $\begin{array}{l}-0.345^{\star \star \star} \\
(0.094)\end{array}$ & $\begin{array}{l}-0.265^{\star *} \\
(0.094)\end{array}$ & $\begin{array}{l}-0.466^{*} \\
(0.249)\end{array}$ & $\begin{array}{l}-0.363^{* *} \\
(0.140)\end{array}$ & $\begin{array}{l}0.273 \\
(0.261)\end{array}$ \\
\hline PhD Year & $\begin{array}{l}-0.032^{* *} \\
(0.013)\end{array}$ & $\begin{array}{l}-0.004 \\
(0.005)\end{array}$ & $\begin{array}{l}0.001 \\
(0.005)\end{array}$ & $\begin{array}{l}-0.024^{* * *} \\
(0.006)\end{array}$ & $\begin{array}{l}-0.012^{*} \\
(0.006)\end{array}$ & $\begin{array}{l}-0.008 \\
(0.020)\end{array}$ & $\begin{array}{l}-0.013 \\
(0.008)\end{array}$ & $\begin{array}{l}0.022 \\
(0.020)\end{array}$ \\
\hline
\end{tabular}

Type of Institution 


\begin{tabular}{|c|c|c|c|c|c|c|c|c|}
\hline $\begin{array}{r}\text { Private } \\
\text { University }\end{array}$ & $\begin{array}{l}-0.097 \\
(0.194)\end{array}$ & $\begin{array}{l}-0.254^{* * *} \\
(0.094)\end{array}$ & $\begin{array}{l}-0.623^{\star * *} \\
(0.089)\end{array}$ & $\begin{array}{l}-1.104^{* * *} \\
(0.154)\end{array}$ & $\begin{array}{l}-0.819^{\star * *} \\
(0.143)\end{array}$ & $\begin{array}{l}-0.636 \\
(0.477)\end{array}$ & $\begin{array}{l}-0.880^{\star * *} \\
(0.171)\end{array}$ & $\begin{array}{l}-0.744^{\star *} \\
(0.371)\end{array}$ \\
\hline $\begin{array}{r}\text { Public } \\
\text { Polytechnic }\end{array}$ & $\begin{array}{l}-0.318 \\
(0.209)\end{array}$ & $\begin{array}{l}-0.390^{* * *} \\
(0.129)\end{array}$ & $\begin{array}{l}-0.636^{\star \star \star} \\
(0.123)\end{array}$ & $\begin{array}{l}-0.426^{* \star *} \\
(0.133)\end{array}$ & $\begin{array}{l}-0.030^{* * *} \\
(0.114)\end{array}$ & $\begin{array}{l}-1.165^{\star \star \star} \\
(0.318)\end{array}$ & $\begin{array}{l}-0.666^{\star *} \\
(0.283)\end{array}$ & $\begin{array}{l}-0.434 \\
(0.478)\end{array}$ \\
\hline $\begin{array}{r}\text { Private } \\
\text { Polytechnic }\end{array}$ & $\begin{array}{l}-0.069 \\
(0.308)\end{array}$ & $\begin{array}{l}0.069 \\
(0.267)\end{array}$ & $\begin{array}{l}-1.155^{\star * *} \\
(0.264)\end{array}$ & $\begin{array}{l}-0.748^{*} \\
(0.446)\end{array}$ & $\begin{array}{l}-0.856 \\
(0.556)\end{array}$ & $\begin{array}{l}-2.510 \\
(1.858)\end{array}$ & $\begin{array}{l}-0.138 \\
(0.505)\end{array}$ & $\begin{array}{l}0.033 \\
(0.767)\end{array}$ \\
\hline $\begin{array}{l}\text { Number of } \\
\text { observations }\end{array}$ & 398 & 1182 & 2083 & 2450 & 1882 & 233 & 953 & 211 \\
\hline F-statistic & $1.821^{*}$ & $9.791^{\star * *}$ & $30.364^{* \star *}$ & $19.967^{\star \star \star}$ & $8.477^{\star \star \star}$ & $3.450^{\star * *}$ & $6.178^{\star * *}$ & 1.238 \\
\hline$R^{2}$ & 0.027 & 0.048 & 0.081 & 0.036 & 0.026 & 0.084 & 0.038 & 0.035 \\
\hline
\end{tabular}

When considering as the dependent variable a broader definition of International Publications including all outlets - the results do not change significantly compared to the previous analysis. In fact, the effect of having a $\mathrm{PhD}$ abroad is still very dependent on which field of education we are focusing on. The effect of the variable is significantly positive in "Arts and Humanities" and "Social Sciences, Commerce and Law", as it was when only the international journals were considered. A negative effect of taking the PhD abroad was identified in "Sciences" and "Engineering, Manufacturing and Construction", and non-significant effects were estimated for all other fields. Again, this reinforces that our theoretical expectations are not mirrored in the results, at least in all fields of education.

\section{CONCLUSIONS}

In this article and based on a mandatory survey conducted by the Portuguese Agency for Assessment and Accreditation of Higher Education on the HEls staff, it was attempted to understand the relationship between the types and number of outputs that the respondents declared in that questionnaire with some researchers' characteristics. The characteristic we were interested in testing was if there was any correlation between the fact that the respondent obtained its $\mathrm{PhD}$ degree abroad and their self-reported outputs. As we concluded in the first steps of this article, we had the theoretical belief that there could be a positive impact due to a greater propensity of this type of PhD holders to collaborate (more) internationally in research (and teaching) activities, to a greater and more varied research networks and contacts, and also due to the evidence in the literature that mobility is a driver for research performance and that international collaboration fosters future research outputs. In sum, those who went abroad can be classified as those with the vest human and social capitals. We have also explained the relevance of this question for Portugal, in the framework of the Scientific and Innovation Policies, and given the relatively high number of $\mathrm{PhD}$ degrees that were taken abroad, with that figure being $27 \%$ for our sample. The analysis of the linear regression leaves no doubts regarding the effects of having a PhD abroad: on average, having taken the PhD abroad means that more international publications (both when considering only journal articles and all international outlets) were likely to be reported by our respondents. However, when checking for the robustness of these effects broken down by the ISCED-97 fields of education, that effect does not hold for most fields, being only significantly positive for "Arts and Humanities" and "Social Sciences, Commerce and Law", while having null and negative effects for other fields, suggesting that, after all, the overall effect verified earlier was due only to the effect of this variable on some fields. This somehow contradicts some findings from the literature review, as, for example, what Rostan and Ceravolo [39] concluded that international research collaboration is more frequent among academics from science and medical sciences, less frequent among academics from both humanities and engineering, with those from the social sciences in between. Nevertheless, this refers to international research collaboration, which does not necessarily implies research outputs, as international articles. On this, and as a basis for future research on the topic, it is also important to acknowledge the advantages and limitations of our database. The database includes all PhDs in Portugal that were working for a $\mathrm{HEl}$, and therefore, it covers most researchers that were active during the period. The response towards the questionnaire was mandatory, but the respondents had a very strong incentive to present their best research results in the outputs window, given that they would strengthen the HEls results they belonged to. However, the major caveat is that each researcher could only identify five of their research outputs. We believe that this may be conditioning our results and underestimating the true effects of having a PhD abroad 
in the research productivity and dissemination abilities of the respondents, as this caveat hindered mostly the researchers that had way more than those five research outputs, which effect we believe would have been stronger for those having the $\mathrm{PhD}$ abroad. This provides a stepping-stone for future research. Considering the future availability of quantitative data, this or future studies would be enriched with the whole research output production and dissemination and not only with the selfreported ones, as well as with a survey on the perceptions of a sample extracted from these respondents, in order to enhance knowledge about the motivations of $\mathrm{PhD}$ students to do their $\mathrm{PhDs}$ abroad and to compare this with the reasons that lead Portuguese students to choose an international $\mathrm{HEl}$ to do a PhD, and/or even to understand differences in international mobility across disciplines.

Acknowledgments: This work was financially supported by the POCI-01-0145-FEDER-029427funded by FEDER, through COMPETE2020 - Programa Operacional Competitividade e Internacionalização (POCI), and by national funds (OE), through FCT/MCTES (Portugal).

\section{REFERENCES}

1.Barré, R., et al., Measuring the integration and coordination dynamics of the European Research Area. Science and Public Policy, 2013. 40(2): p. 187-205.

2.Abramo, G., C.A. D'Angelo, and F. Di Costa, Research collaboration and productivity: is there correlation? Higher Education, 2009. 57(2): p. 155-171.

3.Abramo, G., C.A. D'Angelo, and M. Solazzi, The relationship between scientists' research performance and the degree of internationalization of their research. Scientometrics, 2010. 86(3): p. 629-643.

4.Horta, H. and J.M. Santos, The Impact of Publishing During PhD Studies on Career Research Publication, Visibility, and Collaborations. Research in Higher Education, 2016. 57(1): p. 28-50.

5.Patrício, M.T., et al., Faculty-exchange programs promoting change: motivations, experiences, and influence of participants in the Carnegie Mellon University-Portugal Faculty Exchange Program. Tertiary Education and Management, 2018. 24(1): p. 1-18.

6.Jonkers, K. and L. Cruz-Castro, The internationalisation of public sector research through international joint laboratories. Science and Public Policy, 2010. 37(8): p. 559-570.

7.Decramer, A., S. Goeminne, and C. Smolders, The impact of internationalization on volume and quality of scholarly publication performance. Public Money \& Management, 2013. 33(2): p. 111-117.

8.Kivistö, J., E. Pekkola, and A. Lyytinen, The influence of performance-based management on teaching and research performance of Finnish senior academics. Tertiary Education and Management, 2017. 23(3): p. 260-275.

9.Yokoyama, K., The effect of the research assessment exercise on organisational culture in English universities: Collegiality versus managerialism. Tertiary Education and Management, 2006. 12(4): p. 311-322.

10.Cañibano, C., et al., The evaluation of research excellence and the dynamics of knowledge production in the humanities: The case of History in Spain. Science and Public Policy, 2018: p. scy025-scy025.

11.Carvalho, T. and S. Diogo, Políticas de Ciência e Inovação no Quadro da Sociedade do Conhecimento. Efeitos no Emprego Científico [Science and Innovation Policies in the Knowledge Society Framework]. , in Políticas Públicas, Inovação e Emprego [Public Policies, Innovation and Employment]. , M.M. Serrano and P. Neto, Editors. 2018, SmartBook: Alcochete.

12.Rossi, F., Universities' access to research funds: Do institutional features and strategies matter? Tertiary Education and Management, 2009. 15(2): p. 113-135.

13.COM, Erasmus-Facts, Figures \& Trends. The European Union Support for Student and Staff Exchanges and University Cooperation in 2013-2014 2015, European Commission: Brussels. p. 40.

14.EACEA/Eurydice, The European Higher Education Area in 2015: Bologna Process Implementation Report. 2015, European Commission: Luxembourg.

15.Davies, M., M. Devlin, and M. Tight, Interdisciplinary higher education: Perspectives and practicalities. 2010: Emerald Group Publishing Limited.

16.Brew, A., Academic research and researchers. 2009: McGraw-Hill Education (UK).

17.Edler, J. and P. Boekholt, Benchmarking national public policies to exploit international science and industrial research: a synopsis of current developments. Science and Public Policy, 2001. 28(4): p. 313-321.

18. Edler, J., H. Fier, and C. Grimpe, International scientist mobility and the locus of knowledge and technology transfer. Research Policy, 2011. 40(6): p. 791-805.

19.Vertovec, S., Transnational networks and skilled labour migration. 2002.

20.Kwiek, M., The internationalization of research in Europe: A quantitative study of 11 national systems from a micro-level perspective. Journal of Studies in International Education, 2015. 19(4): p. 341-359.

21.Saxenian, A., BRAIN CIRCULATION. How high-skill immigration makes everyone better off. Brookings Review, 2002. 20(1): p. 28-31.

22.Schiller, N.G., L. Basch, and C. Blanc-Szanton, Towards a definition of transnationalism. Introductory remarks and research questions. Annals of the New York Academy of Sciences, 1992. 645: p. ix-xiv.

23.Ackers, L., Internationalisation, mobility and metrics: A new form of indirect discrimination? Minerva, 2008. 46(4): p. 411-435. 
24.Marginson, S. and M. van der Wende, Europeanisation, international rankings, and faculty mobility: Three cases in higher education globalisation. Higher education to, 2009. 2030: p. 109-41.

25.Van der Wende, M., Internationalization of higher education in the OECD countries: Challenges and opportunities for the coming decade. Journal of Studies in International Education, 2007. 11(3-4): p. 274289.

26.Van Der Wende, M., International academic mobility: towards a concentration of the minds in Europe. European review, 2015. 23(S1): p. S70-S88.

27.Maoz, Z., Networks of nations: The evolution, structure, and impact of international networks, 1816-2001. Vol. 32. 2010: Cambridge University Press.

28.Jonkers, K. and R. Tijssen, Chinese researchers returning home: Impacts of international mobility on research collaboration and scientific productivity. Scientometrics, 2008. 77(2): p. 309-333.

29.Tent, M., International co-operation in R\&D: The experiences of the European Community. Science and Public Policy, 1990. 17(5): p. 293-295.

30.Luijten-Lub, A., M. Van der Wende, and J. Huisman, On cooperation and competition: A comparative analysis of national policies for internationalisation of higher education in seven Western European countries. Journal of studies in international education, 2005. 9(2): p. 147-163.

31.Kantola, M. and J. Hautala, Internationalisation Network: A Finnish Experience. Tertiary Education and Management, 2008. 14(1): p. 43-56.

32.Hemmings, B., D. Hill, and J. Sharp, Research Experiences of Staff within a Specialist UK Higher Education Institution: Challenges, opportunities and priorities. Tertiary Education and Management, 2013. 19(1): p. 52-67.

33.De Wit, H., Measuring Success in the Internationalisation of Higher Education: an Intro-duction. de Wit, Hans (Hrsg.), 2009: p. 1-8.

34.Sá, N., A.P. Ribeiro, and V. Carvalho, International collaboration and knowledge creation: Evidence from economics in Portuguese academia. Science and Public Policy, 2017. 44(1): p. 50-64.

35.Rostan, M. and F.A. Ceravolo, The internationalisation of the academy: convergence and divergence across disciplines. European Review, 2015. 23(S1): p. S38-S54.

36.Woolley, R., et al., Research collaboration in the social sciences: What factors are associated with disciplinary and interdisciplinary collaboration? Science and Public Policy, 2015. 42(4): p. 567-582.

37. Baird, L., Departmental Publication Productivity and Reputational Quality: Disciplinary differences. Tertiary Education and Management, 2009. 15(4): p. 355-369.

38. Teichler, U., Internationalisation as a challenge for higher education in Europe. Tertiary Education and Management, 1999. 5(1): p. 5-23.

39. Zitt, M. and E. Bassecoulard. S\&T networks and bibliometrics: The case of international scientific collaboration. in 4th Congress on proximity economics: Proximity, Networks and Coordination, June. 2004.

40. Kahn, M., Co-authorship as a proxy for collaboration: a cautionary tale. Science and Public Policy, 2018. 45(1): p. 117-123.

41. Bazeley, P., Conceptualising research performance. Studies in Higher Education, 2010. 35(8): p. 889903.

42. Kyvik, S. and D.W. Aksnes, Explaining the increase in publication productivity among academic staff: a generational perspective. Studies in Higher Education, 2015. 40(8): p. 1438-1453.

43. Smeby, J.C., The impact of massification on university research. Tertiary Education and Management, 2003. 9(2): p. 131-144.

44. Lynch, K., Control by numbers: new managerialism and ranking in higher education. Critical Studies in Education, 2015. 56(2): p. 190-207.

45. Santiago, R. and T. Carvalho, Academics in a new work environment: The impact of new public management on work conditions. Higher Education Quarterly, 2008. 62(3): p. 204-223.

46. Kok, S.K., et al., The Move Towards Managerialism: Perceptions of staff in "traditional" and "new" UK universities. Tertiary Education and Management, 2010. 16(2): p. 99-113.4

47. DGEEC, Produção Científica Portuguesa: Séries Estatísticas 2005-2015. 2016, Direção-Geral de Estatísticas da Educação e Ciência: Lisbon.

48. Ruivo, B., As instituições de investigação e a política de ciência, in Ciência em Portugal, J.M. Gago, Editor. 1991, Imprensa Nacional—Casa da Moeda: Lisboa. p. 25-48.

49. Bruckmann, S. and T. Carvalho, The reform process of Portuguese higher education institutions: from collegial to managerial governance. Tertiary Education and Management, 2014. 20(3): p. 193-206.

50. Santiago, R., T. Carvalho, and A. Ferreira, Changing knowledge and the academic profession in Portugal. Higher Education Quarterly, 2015. 69(1): p. 79-100.

51. Santiago, R., T. Carvalho, and R. Relva, Research and the universities' image. European Journal of Education, 2008. 43(4): p. 495-512.

52. Heitor, M. and H. Horta, Science and Technology in Portugal: From Late Awakening to the Challenge of Knowledge-Integrated Communities, in Higher Education in Portugal 1974-2009: A Nation, a Generation, G. Neave and A. Amaral, Editors. 2012, Springer Netherlands: Dordrecht. p. 179-226. 